Rajamanickam, T., Waidyasekara, K.G.A.S. and Pandithawatta, T.P.W.S.I., 2019. Conceptual framework for green supply chain practices in construction industry. In: Sandanayake, Y.G., Gunatilake, S. and Waidyasekara, A. (eds). Proceedings of the $8^{\text {th }}$ World Construction Symposium, Colombo, Sri Lanka, 8-10 November 2019, pp. 200-209. DOI: doi.org/10.31705/WCS.2019.20. Available at: https://2019.ciobwcs.com/papers

\title{
CONCEPTUAL FRAMEWORK FOR GREEN SUPPLY CHAIN PRACTICES IN CONSTRUCTION INDUSTRY
}

\author{
Tharshiha Rajamanickam ${ }^{1}$, K.G.A.S. Waidyasekara ${ }^{2}$ and \\ T.P.W.S.I. Pandithawatta ${ }^{3}$
}

\begin{abstract}
The construction industry plays an important role in improving quality of the environment. However, it was also found out that the construction activities create negative impacts on the environment. Reducing the negative environmental impact of the construction industry is one of the major challenges in the $21^{\text {st }}$ century. However, regardless of the significance of this problem, limited efforts to deal with the negative effects have been largely fragmented and disjointed. Green Supply Chain Management is considered as one of the main efforts, which aim to integrate environmental parameters within the supply chain management. It reduces carbon emissions and improves environmental performances of organizations. The trend towards developing Green Supply Chain is now increasing among various industries. In the recent past, enterprises have started Green Supply Chain Management for the purpose of securing competitive advantages over other initiative due to the increase of international conventions related to the recent climate change, the global environmental protection regulations, the stakeholders and investors' need for environmental suitability and the consumer's choice for environmentally friendly products. Therefore, this paper aims to critically review the secondary data on Supply Chain Management, Sustainable Supply Chain Management, and Green Supply Chain Management in the construction industry. Finally, the paper presents a conceptual framework integrating concepts for Green Supply Chain Management practices to the construction sector.
\end{abstract}

Keywords: Green Supply Chain Management; Supply Chain Management; Sustainable Supply Chain Management.

\section{INTRODUCTION}

Supply chain management (SCM) is an incorporated approach, which assimilate the service providers to the end customers or suppliers to manufacturers (Fantazy et al., 2010). Retail organizations and manufacturing organizations are integrating SCM and from that they are able to enhance the efficiency and effectiveness of their business functions, but the construction industry has been slow to implementing SCM (Love et al., 2000). When compared to other sectors, construction supply shows some characteristic differences while it is an incorporated set of practice, which maintains and coordinate the total Supply Chain (SC) from raw material to end clients However, De Silva et al. (2008)

\footnotetext{
${ }^{1}$ Department of building Economics, University of Moratuwa, Sri Lanka, Tharshiharajamanickam@yahoo.com

${ }^{2}$ Department of building Economics, University of Moratuwa, Sri Lanka, anuradha@uom.lk

${ }^{3}$ Department of building Economics, University of Moratuwa, Sri Lanka, sonalitpw@gmail.com
} 
stated that lack of resources is one of the main challenges faced by the Sri Lankan construction industry. In order to attain the potential future demand, companies wish to make their SCs in a way that doesn't impact the environment (Mahler, 2007). Especially in Sri Lankan context, with the booming economic development has tend the industry to focus on large scale construction projects, and it automatically leads to the environment resource depletion, so environment friendly development is needed in order to manage consistency between human and environment. Therefore, this research aimed to develop a conceptual framework for assessing the adaptation of Green Supply Chain Management (GSCM) practices in Sri Lankan construction industry.

\section{RESEARCH METHODOLOGY}

Research methodology refers to the overall approach to the research process that is from the theoretical underpinning to the collection and analysis of data. First step of the research process is conducting literature review. As Uyangoda (2010) mentions, literature review is a critical assessment of the existing body of knowledge on the theme or problem. Mainly, literature evidence was taken by referring journal articles, books, conference proceedings, industry reports and documents. During the literature survey the details relating to Supply Chain Management, Sustainable Supply Chain Management, and Green Supply Chain Management was reviewed. At the end a conceptual framework was built to show the relationships between those key areas.

\section{LITERATURE REVIEW}

\subsection{Supply Chain AND SuPPly Chain MANAGEMENT}

Supply Chain (SC) is the combination of activities that a firm proceeds to convert the raw materials into a final product. The most effective and efficient types of SC are capable to deliver quality goods in a quicker and cheaper manner (Wisner et al., 2014). Supply Chain Management (SCM) considered as a wide range of activities required to plan, control and execute a product, from purchasing raw materials to distribution of final product to the customer. SCM process improves the quality of product and reduces cost and delivers product, services, and information (Croxton et al., 2001). In other words, these SCM processes help firms to reach its objectives in effective and the efficient manner (Johnson, 2016). Tan (2001) stated that planning, product design and development, manufacturing and order fulfilment, customer management, and return are the process of SCM. By implementing SCM systems, the company can minimise the waste generation, costs and transportation delays in a systematic way. Improved inventory income, increased profits, cost reduction across the chain, increased customer awareness, more reliable on-time delivery, customer satisfaction, reduced purchasing costs, reduced inventory costs, proper inventory levels in the chain, minimize delays, and deliver good customer service were identified as some of the advantages of SCM (Fawcett et al., 2008).

\subsection{COnStruction Supply Chain MANAGEMENT}

In order to increase performance of the construction sector, adoption of effective SCM is essential. Construction Supply Chain (CSC) is more complex compared to manufacturing supply chain, because of the large number of participants and comprehensiveness of the process. Effective and more efficient Construction Supply Chain Management (CSCM) provides multi-team communications in construction and increase the relationships 
between clients, consultants, contractors and subcontractors (Butković et al., 2016). CSCM is defined as the strategic management of information flows, activities, tasks, and processes, involving various networks of independent organizations and linkages (upstream and downstream) which produce value that is delivered to the owner in the form of a finished project (Cox and Ireland, 2002).

CSCM guarantee reliable material and labour flows to the site to avoid disturbance to the workflow. Moreover, it helps to improve the performance and productivity by minimizing the delays in the construction (Beheraa et al., 2015; Saad et al., 2002). Adoption and implementation of SCM in the construction industry is not easy due to the presence of many barriers. Failure to share project information, fear of loss of control, lack of selfawareness, lack of knowledge of the project complexity, inability to identify project goals, lack of understanding of SC, narrow-minded thinking, unfair strategies, and lack of support are identified major barriers of CSCM (Aloini et al., 2012; Panova and Hilletofth, 2018).

\subsection{NEGATIVE ENVIRONMENTAL IMPACT OF CONSTRUCTION INDUSTRY AND REQUIREMENT OF SUSTAINABLE CONCEPT}

Construction projects have a major impact on the global environment in a negative way through energy, materials, chemical products and waste production (Li et al., 2010). According to the International Energy Agency (2018) the construction sector contributes to $23 \%$ of air pollution, $50 \%$ of climatic change, $40 \%$ of water pollution, and $50 \%$ of landfill wastes. Furthermore, this report stated that the construction industry accounts for $40 \%$ of worldwide energy usage and responsible for $40 \%$ of global carbon emissions and $25 \%$ of global waste. Nowadays, many countries around the world are considering negative impacts to protect human, environment and resources. Therefore, the construction projects should be designed to have the greatest positive impact and the least negative impact on the environment (Enshassi et al., 2015).

Sustainable construction has been commonly defined as the growth that meets the needs of the present without compromising the capacity of future generations to meet their own needs (Singh and Trivedi, 2016). It incorporates elements of economic ability, environmental performance and social obligation (Gold et al., 2010). However, the incorporation of environmental, economic and social paradigms to achieve sustainable development is a main task for all industries. Initially, sustainability concepts primarily focus on environmental issues with less attention of social and economic concerns (Gold et al., 2010). Further this approach minimises the pollution and waste compared to SCM. Pagell and Shevchenko, (2013) said that Sustainable Supply Chain Management (SSCM) is "the designing, organizing, coordinating, and controlling of supply chains to become truly sustainable with the minimum expectation of a truly sustainable supply chain being to maintain economic viability, while doing no harm to social or environmental systems".

The most influencing barrier to implement SSCM is the lack of support in developing countries (Vermeulen, 2006). It includes low levels of regulation, and lack of knowledge gap between top government officers. There is a common lack of awareness about sustainable practice and sustainable issues among consumers and suppliers of the developing countries (Soda et al., 2015) and a lack of request from customers for sustainable products. Green upfront costs can be very high for organizations in developing countries (Li et al., 2015). 
When dealing with environmental issues, the organization focuses on green supply management programs designed to reduce harmful effects in the environment. Green construction goes a step further than sustainability and it minimizes the environmental impact in the construction process (Soda et al., 2015).

\subsection{GREen SUPPLY Chain MANAGEMENT IN THE CONSTRUCTION INDUSTRY}

Over the past decade, the growing impact of global warming, climate change, waste and air pollution problems have involved increasing worldwide consideration of experts to think more environmentally friendly and solution towards "Green" (Rostamzadeh et al., 2015). Further, the environmental, social and economic impacts of the construction industry are increasing, driving the demand for sustainable construction. Use of large number of natural resources, environmental pollution and the immense usage of energy in production of materials create a significant impact on the environment (Balasubramanian, 2012). Green Supply Chain Management (GSCM) aims to integrate environmental thinking into SCM (Srivastava, 2007). As an alternative of reducing the dangerous things of business and SC operations, Green Supply Chain (GSC) minimizes air, water and waste pollution. Moreover, it also improve companies' performance in terms of less waste manufacturing, recycling, reducing production costs, improving asset efficiency, positive image building and customer (Chun et al., 2007; Fang and Zhang, 2018).

GSCM definition of construction industry integrates sustainable practices into upstream and downstream SCM, bringing long-term benefits by applying environmental and social behaviour responsible for all supply chain members (Chowdhury et al., 2016). The main aim of green practices is to reduce the negative environmental effects linked with construction activities. Some authors identified that green design, green construction, green material management, reverse logistics, and green operation and maintenance are the main green practices which falls under construction industry (Wibowo et al., 2018).

\subsubsection{Green Design}

Green design is the most important stage in GSCM practices, decisions taken at this stage will be influenced at every stage of the life cycle of the building from planning to material recycle and reuse phase (Srivastava, 2007). The purpose of the green design is to minimize negative environmental impacts of the construction projects throughout environmentally friendly way. The important aspect of green product design comprises the selection of raw material with high percentage of recycled content and small embodied energy. Green design reduces the environmental impact of building design and process ( $\mathrm{Ng}$ et al., 2012). The dimensions of the green product design are design, innovation capability, product safety, environmental control, and building and environmental management (Govindan et al., 2015).

\subsubsection{Green Material Management}

Green material management is a method to replace more favourable activities or materials with potentially hazardous one. Green materials management selecting criteria emphasise that materials used in construction should be easily fragmented, flexible, or useful in restructuring existing processes (Nur et al., 2018). Material planning, material storage, green procurement, material handling, green material selection and green material sourcing are the main processes of green material management (Hafezalkotob, 2017). 


\subsubsection{Green Construction}

Main goal of green construction is to eliminate or minimize negative environmental impacts on the design, construction and operation phase in addition to create buildings with a positive impact on the environment. Moreover, Green construction discusses the use of on-site practices to reduce the impact of building environment. Green transportation, on-site management and planning, site operation, residual, and environment society are overall theories that are primary components of green construction (Balasubramanian and Shukla, 2017).

\subsubsection{Green Operation and Maintenance}

Green operation and maintenance programs include teaching, cleaning, work applications and controls for protecting the green materials of the project according to environmental needs. Dimensions of green operation and maintenance are green building, green marketing management and green management policy (Chang et al., 2016; Chen, 2012).

\subsubsection{Reverse Logistics}

Environmental reverse logistics is a series of activities that help to return into forward SC of reusable, remanufacture, and recyclable materials and products (Ghobakhloo et al., 2013). Recycling is demarcated as a way to reuse materials that may otherwise be considered waste in a form other than the primary use. Remanufacturing is the method of returning a used product to at least its original performance. Reuse means a material is used again for the same purpose or may find a new product life in a different function (Ng et al., 2012).

\subsection{BARRIERS AND DRIVERS OF GREEN SUPPLy CHAIN MANAGEMENT}

Table 1 shows the barriers and divers of the GSCM identified by the researchers. GSCM aims to minimize waste and pollution by consolidating environmental thoughts into design and end-life management. Implementation of these chains are influenced by the drivers and the barriers. The barriers are the forces which prevent the implementation of GSCM. Moreover, drivers are defined as the strengths to inspire organisations for the implementation of green supply chain.

Table 1: Barriers and drivers of green practice

\begin{tabular}{|c|c|c|c|c|c|c|c|c|}
\hline \multirow[b]{2}{*}{ Barriers and Drivers } & \multicolumn{8}{|c|}{ Literature source } \\
\hline & 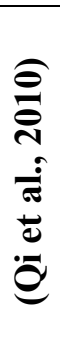 & 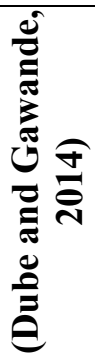 & 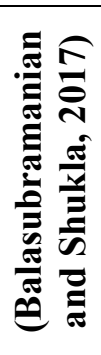 & 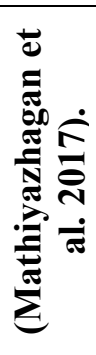 & 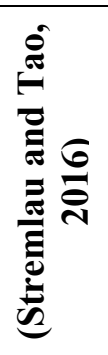 & 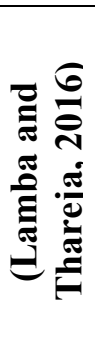 & 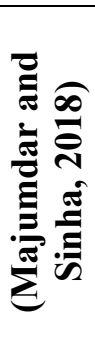 & 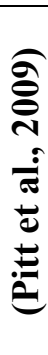 \\
\hline \multicolumn{9}{|l|}{ Internal Barriers } \\
\hline $\begin{array}{l}\text { Lack of availability of skilled human } \\
\text { resource }\end{array}$ & & & $\mathrm{X}$ & & & $X$ & & \\
\hline $\begin{array}{l}\text { Lack of top level management } \\
\text { commitment }\end{array}$ & & & $X$ & & & & & \\
\hline
\end{tabular}




\begin{tabular}{|c|c|c|c|c|c|c|c|c|}
\hline \multirow[b]{2}{*}{ Barriers and Drivers } & \multicolumn{8}{|c|}{ Literature source } \\
\hline & 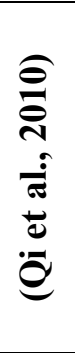 & 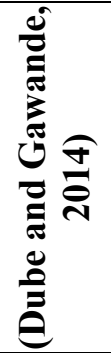 & 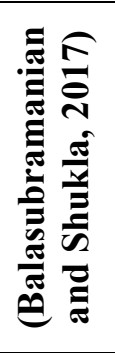 & 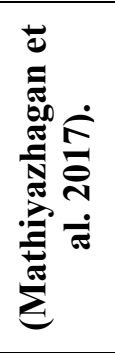 & 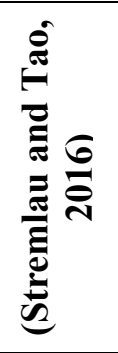 & 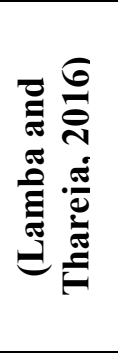 & 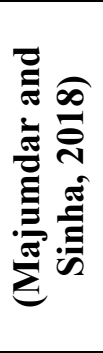 & 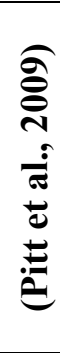 \\
\hline $\begin{array}{l}\text { Capital requirement for GSCM } \\
\text { implementation }\end{array}$ & & & $\mathrm{X}$ & & & & & \\
\hline $\begin{array}{l}\text { Lack of technical knowledge and } \\
\text { experience }\end{array}$ & & & & & $X$ & $X$ & $\mathrm{X}$ & \\
\hline Lack of training in GSCM & & $X$ & & & & & $X$ & \\
\hline $\begin{array}{l}\text { Lack of acceptance of new } \\
\text { technology }\end{array}$ & & & & & $\mathrm{X}$ & & & \\
\hline \multicolumn{9}{|l|}{ External Barriers } \\
\hline Lack of green professionals & & & $\mathrm{X}$ & & & & & \\
\hline $\begin{array}{l}\text { Customer unawareness towards } \\
\text { GSCM practices }\end{array}$ & & & $\mathrm{X}$ & & & $\mathrm{X}$ & & \\
\hline $\begin{array}{l}\text { Shortage of green suppliers or } \\
\text { recyclable materials }\end{array}$ & & $\mathrm{X}$ & & & & & & \\
\hline Lack of stakeholder engagement & & $\mathrm{X}$ & & & $\mathrm{X}$ & & & \\
\hline $\begin{array}{l}\text { Lack of government initiative } \\
\text { systems }\end{array}$ & & $\mathrm{X}$ & $\mathrm{X}$ & & & $\mathrm{X}$ & $X$ & \\
\hline Tight stakeholder deadlines & & & & & & $\mathrm{X}$ & & \\
\hline \multicolumn{9}{|l|}{ External drivers } \\
\hline Government rules and legislation & $\mathrm{X}$ & $\mathrm{X}$ & & & & & & \\
\hline Society or public pressure & & & & & & $\mathrm{X}$ & & \\
\hline $\begin{array}{l}\text { Client or Customer awareness and } \\
\text { pressure }\end{array}$ & & & & & & & & $\mathrm{X}$ \\
\hline Stakeholder pressure & & & & & & & & $\mathrm{X}$ \\
\hline $\begin{array}{l}\text { Improve the image of the } \\
\text { construction industry }\end{array}$ & & & & & & & & $\mathrm{X}$ \\
\hline Competitor pressure & & $X$ & & & & & & \\
\hline \multicolumn{9}{|l|}{ Internal drivers } \\
\hline $\begin{array}{l}\text { Developers or Contractor's } \\
\text { environmental mission or } \\
\text { environmental commitment }\end{array}$ & & & & & & $\mathrm{X}$ & & $\mathrm{X}$ \\
\hline Investors and shareholders' pressure & & $\mathrm{X}$ & & & & & & \\
\hline Enhance reputation & $\mathrm{X}$ & & & & & & & \\
\hline $\begin{array}{l}\text { Increased employee or labour } \\
\text { productivity }\end{array}$ & $\mathrm{X}$ & & & & & & & \\
\hline Support from top managers & & $X$ & & & & & & $X$ \\
\hline
\end{tabular}


According to Table 1, the lack of a government initiative system is identified as the main barrier to the implementation of green practice, that this barrier was highlighted by four reference materials However, lack of knowledge and experience between stakeholders of SC about implementing GSCM also play a major role in the GSCM implementation because this barrier was commonly identified in many sources. Likewise, when considering the drivers of GSCM practices, the goal of company's developer or contractor's for his company and government rules and legislation for environment management plans were highlighted by two authors as most important drivers of green practices.

\subsection{CONCEPTUAL FRAMEWORK FOR GREEN SUPPLy CHAIN MANAGEMENT IN CONSTRUCTION INDUSTRY}

The framework proposed (refer Figure 1) is based on the extensive review of literature to enable experts, managers and researchers to get the complete perspective of Green supply chain management practices in the construction industry. Green design, green construction, green material management, reverse logistics, and green operation and maintenance are the main green practices, which come under construction industry. The conceptual framework of green supply chain practices in the construction industry is presented in Figure1. These green supply chain practices in the construction industry is a cyclical process. In here materials from the reverse logistic were used in an another construction activity therefore waste generation from these GSCM is comparability low than traditional construction method.

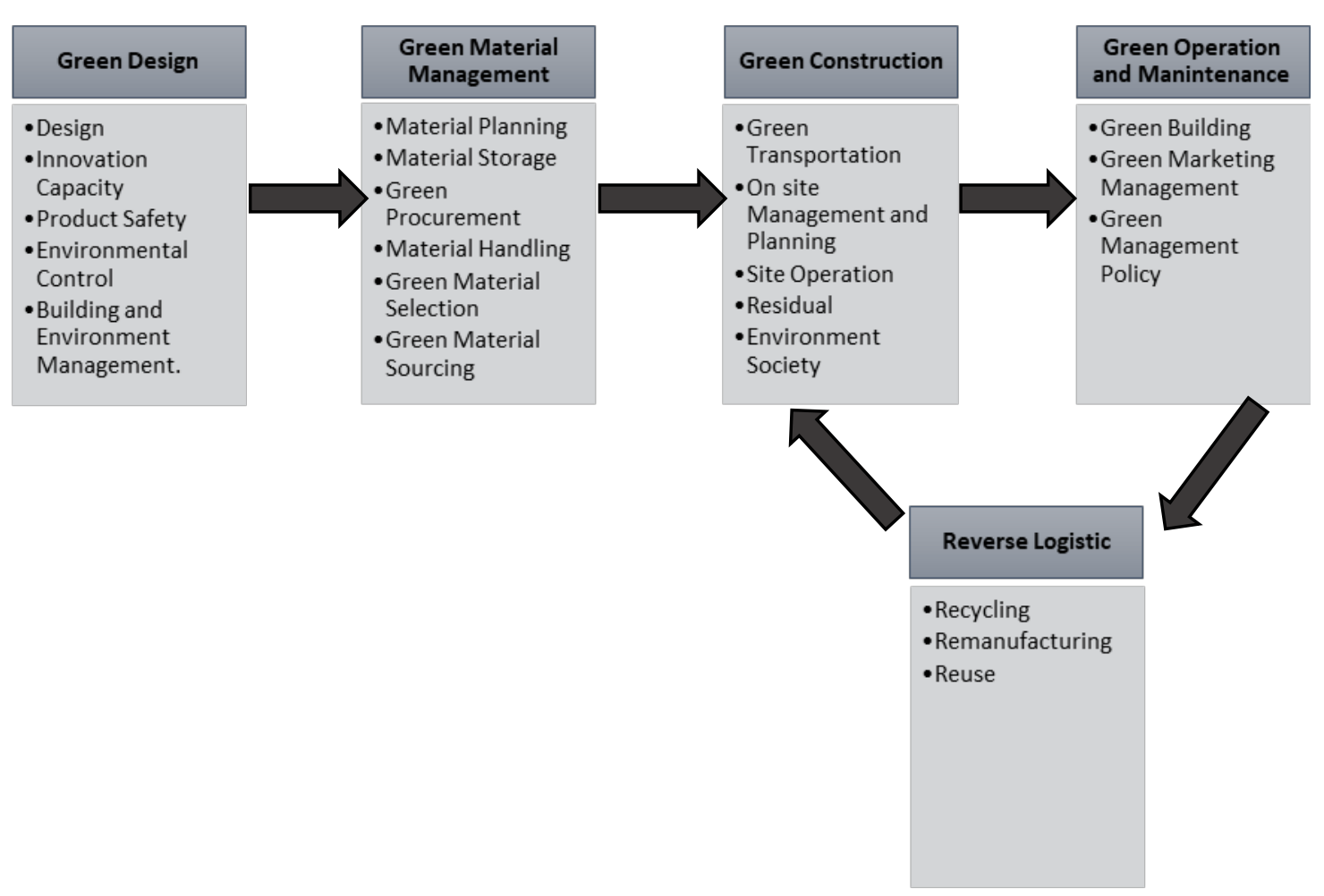

Figure 1: Conceptual framework of green practices in construction industry 


\section{SUMMARY AND WAY FORWARD}

Green construction goes a step further than sustainability and minimizes the environmental impact in the construction process. As the environmental awareness is increasing, firms all over the world are facing a heavy pressure from different stakeholders including government and customers to mitigate their harmful impacts on the environment. When dealing with environmental issues, companies prefer to undertake GSCM programmes that aim to reduce harmful effects to the environment. The aim of this study is to elaborate literature available on green supply chain practices and to develop a conceptual framework of green practices in construction industry. These practices were mainly identified as, green design, green material management, green construction, green operation and maintenance, and reverse logistic. During the next step of the study, the GSC practices that are suitable to the Sri Lankan construction industry will be investigated along with their enablers and barriers. The future implications of this study will be beneficial to other developing countries during the implementation process of GSC practices.

\section{REFERENCES}

Aloini, D., Dulmin, R., Mininno, V. and Ponticelli, S., 2012. Supply Chain Management: A Review of Implementation Risks in The Construction Industry. Business Process Management Journal, 18(5), pp.735-761.

Behera, P., Mohanty, R.P. and Prakash, A., 2015. Understanding construction supply chain management. Production Planning \& Control, 26(16), pp.1332-1350.

Butković, L. L., Kauric, A. G. and Mikulic, J., 2016. Supply Chain Management in the Construction Industry-A Literature Review. In 4th International OFEL Conference on Governance, Management and Entrepreneurship, pp.798-811.

Central Bank, 2017. Annual Report of Central Bank, Sri Lanka: Central Bank of Sri Lanka.

Chang, Y. H., Huang, P. H., Chuang, T. F. and Chang, S. W., 2016. A Pilot Study of the Color Performance of Recycling Green Building Materials. Journal of Building Engineering, 7, pp.114-120.

Chen, C.C., 2012. A Business Strategy Selection of Green Supply Chain Management Via An Analytic Network Process. Computers \& Mathematics with Applications, 64(8), pp.2544-2557.

Chowdhury, M., Upadhyay, A., Briggs, A. and Belal, M., 2016, May. An overview of green supply chain management practices in Bangladesh construction industries. In POMS Conference 2016 (pp. 1-10).

Chun, S. H., Hwang, H. J. and Byun, Y. H., 2007. Green Supply Chain Management in the Construction Industry: Case of Korean Construction Companies. Procedia - Social and Behavioral Sciences, 186, pp.507-512.

Cox, A. and Ireland, P., 2002. Managing Construction Supply Chains: The Common Sense Approach. Engineering, Construction and Architectural Management, 9(5), pp.409-418.

Croxton, K. L., García-Dastugue, S. J., Lambert, D. M. and Rogers, D. S., 2001. The Supply Chain Management Processes. The International Journal of Logistics Management, 12(2), pp.13-36.

De Silva, N., Rajakaruna, R. W. D. W. C. A. B. and Bandara, K. A. T. N., 2008. Challenges Faced By the Construction Industry in Sri Lanka: Perspective of Clients and Contractors, In Proceedings of the symposium conducted at the meeting of the Building Resilience, School of the Built Environment, University of Salford.

Dhull, S. and Narwal, M. S., 2016. Drivers and Barriers in Green Supply Chain Management Adaptation: A State-of-Art Review. Uncertain Supply Chain Management, 4(1), pp.61-76.

Dube, A. S. and Gawande, R. R., 2014. Barriers for Green Supply Chain Management Implementation. SNJB's Late Sau. K. B. Jain College Of Engineering, Chandwad, pp.475-480.

Enshassi, A., Kochendoerfer, B. and Rizq, E., 2015. An Evaluation of Environmental Impacts of Construction Projects. Revista Ingeniería de Construcción, 29(3). 
Fang, C. and Zhang, J., 2018. Performance of Green Supply Chain Management: A Systematic Review and Meta Analysis. Journal of Cleaner Production, 183, pp.1064-1081.

Fantazy, K. A., Kumar, V. and Kumar, U., 2010. Supply Management Practices and Performance in the Canadian Hospitality. International Journal of Hospitality Management, 29(4), pp.685 - 693.

Fawcett, S. E., Magnan, G. M. and McCarter, M. W., 2008. Benefits, Barriers, and Bridges to Effective Supply Chain Management. Supply Chain Management: An International Journal, 13(1), pp.35- 48

Ghobakhloo, M., Tang, S. H., Zulkifli, N. and Ariffin, M., 2013. An Integrated Framework of Green Supply Chain Management Implementation. International Journal of Innovation, Management and Technology, 4(1), p.86.

Gold, S., Seuring, S. and Beske, P., 2010. Sustainable Supply Chain Management and Inter-Organizational Resources: A Literature Review. Corporate Social Responsibility and Environmental Management, 17(4), pp.230-245.

Govindan, K., Rajendran, S., Sarkis, J. and Murugesan, P., 2015. Multi Criteria Decision Making Approaches for Green Supplier Evaluation and Selection: A Literature Review. Journal of Cleaner Production, 98, pp.66-83.

Hafezalkotob, A., 2017. Competition, Cooperation, and Coopetition of Green Supply Chains Under Regulations on Energy Saving Levels. Transportation Review, 97, pp.228-250.

Johnson, G. S. M., 2016. Integrating the Supply Chain... 25 Years on. International Journal of Physical Distribution \& Logistics Management, 46(1), pp.19-42.

Lamba, N. and Thareja, P., 2016. Barriers of Green Supply Chain Management: A Review. Journal of Advanced Research In Manufacturing, Material Science \& Metallurgical Engineering, 3(3\&4), pp.415.

Li, J., Pan, S.Y., Kim, H., Linn, J.H. and Chiang, P.C., 2015. Building green supply chains in eco-industrial parks towards a green economy: Barriers and strategies. Journal of Environmental Management, 162, pp.158-170.

Love, P. E., Li, H., Irani, Z. and Faniran, O., 2000. Total Quality Management and the Learning Organization: A Dialoque for Change in Construction. Construction Management and Economics, 18(3), pp.321 - 331.

Luthra, S., Garg, D. and Haleem, A., 2016. The Impacts of Critical Success Factors for Implementing Green Supply Chain Management Towards Sustainability: An Empirical Investigation of Indian Automobile Industry. Journal of Cleaner Production, 121, pp.142-158.

Mahler, D., 2007. The Sustainable Supply Chain. Supply Chain Management Review, 11(8), pp.59-60.

Majumdar, A. and Sinha, S., 2018. Modeling the Barriers of Green Supply Chain Management in Small and Medium Enterprises: A Case of Indian Clothing Industry. Management of Environmental Quality: An International Journal, 29(6), pp.1110-1122.

Mathiyazhagan, K., Datta, U., Singla, A. and Krishnamoorthi, S., 2018. Identification and prioritization of motivational factors for the green supply chain management adoption: case from Indian construction industries. Opsearch, 55(1), pp.202-219.

Mentzer, J. T., 2004. Fundamentals of supply chain management: twelve drivers of competitive advantage. UK: Sage.

Mentzer, J.T., DeWitt, W., Keebler, J.S., Min, S., Nix, N.W., Smith, C.D. and Zacharia, Z.G., 2001. Defining supply chain management. Journal of Business Logistics, 22(2), pp.1-25.

Muduli, K. and Barve, A., 2013. Empirical investigation of the barriers of Green Supply Chain Management (GSCM) Implementation in Indian mining industries (ICBEMBS'2013). Singapore.

Ng, S. T., Wong, J. M., Skitmore, S. and Veronika, A., 2012. Carbon dioxide reduction in the building life cycle: a critical review. s.1., Thomas Telford Ltd., pp.281-292.

Nur, F., Handayani, N. U. and Wibowo, M. A., 2018. Developing Indicators to Implementing Green Material. EDP Sciences.

O'Brien, W. J., Formoso, C. T., Vrijhoef, R. and London, A. K. eds., 2009. Construction supply chain management: handbook. CRC Press.

Pagell, M. and Shevchenko, A., 2013. Why Research in Sustainable Supply Chain Management Should Have no Future. Journal of Supply Chain Management, 50(1), pp.44-55. 
Panova, Y. and Hilletofth, P., 2018. Managing supply chain risks and delays in construction project. Industrial Management \& Data Systems, 118(7), pp.1413-1431.

Papadopoulos, G. A., Zamer, N., Gayialis, S. P. and Tatsiopoulos, I. P., 2016. Supply Chain Improvement in Construction Industry. Universal Journal of Management, 4(10), pp.528-534.

Pitt, M., Tucker, M., Riley, M. and Longden, J., 2009. Towards Sustainable Construction: Promotion and Best Practices. Construction Innovation, 9(2), pp.201-224.

Qi, G. Y., Shen, L. Y., Zeng, S. X. and Jorge, O. J., 2010. The Drivers for Contractors' Green Innovation: An Industry Perspective. Journal of Cleaner Production, 18(14), pp.1358-1365.

Rostamzadeh, R., Govindan, K., Esmaeili, A. and Sabaghi, M., 2015. Application of Fuzzy VIKOR for Evaluation of Green Supply Chain Management Practices. Ecological Indicators, 49, pp.188-203.

Saad, M., Jones, M. and James, P., 2002. A Review of the Progress Towards the Adoption of Supply Chain Management (SCM) Relationships in Construction. European Journal of Purchasing \& Supply Management, 8, pp.173-183.

Soda, S., Sachdeva, A. and Garg, R.K., 2015. GSCM: practices, trends and prospects in Indian context. Journal of Manufacturing Technology Management, 26, pp.889-910.

Serpell, A. and Heredia, B., 2004. Supply Chain Management in Construction: Diagnosis and Application Issues. Globalisation and Construction, pp.455-466.

Singh, A. and Trivedi, A., 2016. Sustainable Green Supply Chain Management: Trends and Current Practices. Competitiveness Review, 26(3), pp.265-288.

Srivastava, S. K., 2007. Green Supply-Chain Management: A State-of-the-Art Literature Review. International Journal of Management Reviews, 9(1), pp.53-80.

Stremlau, K. and Tao, J., 2016. Green Supply Chain Management Enablers and Barriers in Textile Supply Chains: What factors enable or aggravate the implementation of a GSCM strategy for textile, Thesis (Masters), University of Borås, Faculty of Textiles, Engineering and Business.

Tan, K. C., 2001. A Framework of Supply Chain Management Literature. European Journal of Purchasing \& Supply Management, 7, pp.39- 48.

Thunberg, M. and Rudberg, M., 2017. Categorising on-Site Problems: A Supply Chain Management Perspective on Construction Projects. Construction Innovation, 17(1), pp.90-110.

Vermeulen, W. J., 2006. The Challenge of Greening Global Product Chains Meeting Both Ends. Sustainable Development, 14(4), pp.245-256

Vijayvargy, L., Thakkar, J. and Agarwal, G., 2017. Green Supply Chain Management Practices and Performance. Journal of Manufacturing Technology Management, 28(3), pp.229-323.

Wibowo, M.A., Handayani, N.U., Mustikasari, A., Nurdiana, A. and Soleh, M.N., 2018. Determining Factors for Implementing Green Supply Chain Management in the Construction Industry: A Literature Review. In MATEC Web of Conferences (Vol. 159, p. 01022). EDP Sciences.

Wisner, J. D., Tan, K.C. and Leong, G. K., 2014. Principles of supply chain management: a balanced approach. USA: Cengage Learning.

Zhang, X., Shen, L. and Wu, Y., 2011. Green Strategy for Gaining Competitive Advantage in Housing Development: A China Study. Journal of Cleaner Production, 19(2-3), pp.157-167. 